\title{
Automatic Aquarium Cleaner and Fish Feeder Based on Microcontroller Atmega8535
}

\author{
Bisman Perangin-angin ${ }^{1^{*}}$ and Teopilus Andri Putra Ginting ${ }^{2}$ \\ ${ }^{1,2}$ Department of Physics, Faculty of Mathematics and Natural Science, Universitas Sumatera Utara, \\ Medan 20155, Indonesia
}

\begin{abstract}
The design of an aquarium cleaner and automatic fish feeder based on the Atmega8535 microcontroller has been successfully carried out. Testing is carried out after all components are integrated into one including the overall program that has been made. Testing is done by running the system according to the procedure and observing the system's performance, starting with measuring turbidity and checking the water replacement schedule. The work processes running on the system are analyzed after testing. When the water turbidity level is high, the drain pump will activate and pump water out of the aquarium. After the remaining water level is about $25 \%$, the drain pump will stop, and the filling pump will be active. The fill pump runs until the water level reaches $100 \%$ and then shuts down. After 10 minutes of filling the water, the servo motor will move and drop the fish feed into the aquarium.
\end{abstract}

Keyword: aquarium, water pump, servo motor, microcontroller, Atmega8535.

Received 19 August 2021 | Revised [23 August 2021] | Accepted [27 August 2021]

\section{Introduction}

According to Sirajudhen, et al (2014) nearly 2 million people around the world work in fisheries, including ornamental fish cultivation [1]. This is very likely to provide community livelihoods as ornamental fish cultivators considering the number of ornamental fish enthusiasts is more [2].

Chip or integrated circuit (IC) technology is growing and increasingly sophisticated, providing opportunities for further and complex automation developments. Automation is a system that works automatically and will provide many benefits for humans, namely supporting human tasks to be more efficient, practical and economical. Many human tasks are routinely carried out and require a long time to complete, so they are impractical and a waste of time. One example is the task of changing aquarium water for those who keep ornamental fish and fish for consumption. The aquarium is a place for fish, aquatic plants and other aquatic organisms that have at least one transparent side to be seen [3].

\footnotetext{
*Corresponding author at: Jalan Bioteknologi no.1 Medan, 20155, Indonesia

E-mail address: bisman@usu.ac.id
} 
Water replacement is an act of replacing water with new water so that it can restore its quality and quantity [4]. One way to find out whether the water is good or not is to measure its acidity. For these needs, a pH measurement system design is needed [5]. For periodic water changes, a real time clock is used as a water change scheduler in the aquarium. Meanwhile, to fill and drain water in the aquarium, a water pump with an $\mathrm{AC}$ motor is used which is connected to a microcontroller so that it can work according to a predetermined schedule. Microcontroller is a chip that functions as an electronic circuit controller and can store programs in it [6].

The water pump is a water circulation pump that uses an AC motor as a pump motor. AC motor is a device that converts electrical energy into mechanical energy (rotation). Mechanical energy is obtained because the electric current flowing through the conductor is in a magnetic field so that a mechanical thrust arises [7]. Solenoid valve or solenoid valve has an output hole, an input hole, and an exhaust hole. The input hole serves as a terminal or place for compressed air to enter or supply (service unit), while the output hole serves as a terminal or water outlet, and the exhaust hole serves as a channel to remove compressed air that is trapped when the plunger moves or changes position when the solenoid valve is working [8].

To maintain the cleanliness of the water that is put into the aquarium, a water filter is used which is integrated with the water pump. Boyd in Lesmana (2015) states that the degree of acidity $(\mathrm{pH})$ of water will affect fish appetite and chemical reactions in the water [9]. Filters are important for an aquarium. The function of the aquarium filter is as a water filter and improve water quality for the better. With the aquarium filter, it will be free from piles of dirt both from fish waste and food waste which will later be broken down by bacteria and cause nitrite or ammonia dissolved in water that can poison fish [7].

Monitoring the cleanliness of the water using a water turbidity sensor. Sensors are devices that can receive stimuli and respond with an electrical signal. Stimulus is a quantity, property, or condition that is perceived and converted into an electrical signal. The purpose of a sensor is to respond to an input of physical properties (stimuli) and convert it into an electrical signal through electronic contacts [10]. The impact of turbidity will result in goldfish lack of oxygen and decreased response to food as a result of obstructed termite vision [11].

\section{Methods}

\section{$2.1 \quad$ Block Diagram}

The block diagram of the designed system is as shown in Figure 1, which describes the input and output configuration of the system. In this design the inputs are the turbidity of the water as measured by the turbidity sensor, and the water level as measured by the ultrasonic sensor. There are several types of water level measurement sensors, namely ultrasonic, optical, and electronic sensors [12]. RTC is an electronic clock in the form of a chip that can calculate time (from seconds to years) accurately and maintain / store the time data in real time [13]. When the 
turbidity sensor detects the water is cloudy or when the water change is on schedule, the drain pump will activate and the water will be pumped out of the aquarium. The ultrasonic sensor will measure the water level in the aquarium. If the water level has reached about $25 \%$ of the original water volume, the drain pump will turn off and the water filling pump will actively pump water into the aquarium. When the water level has reached $100 \%$, the filling pump will turn off. After the filling pump is off, 14 minutes later the servo motor will move and drop the fish feed into the aquarium. The control process of this system is carried out by an AVR microcontroller which regulates the process of filling and draining water as well as measuring the water level.

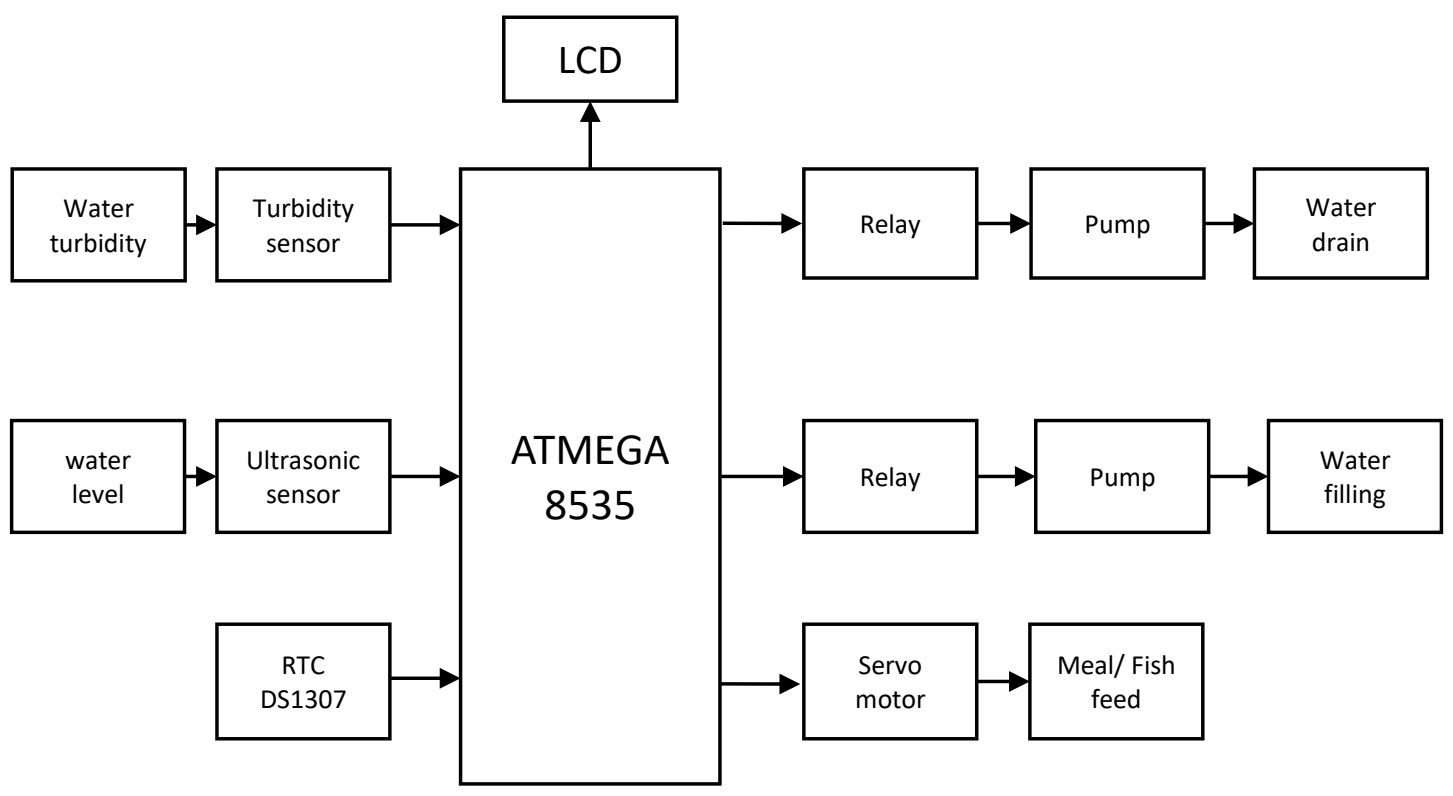

Figure 1. System design block diagram 


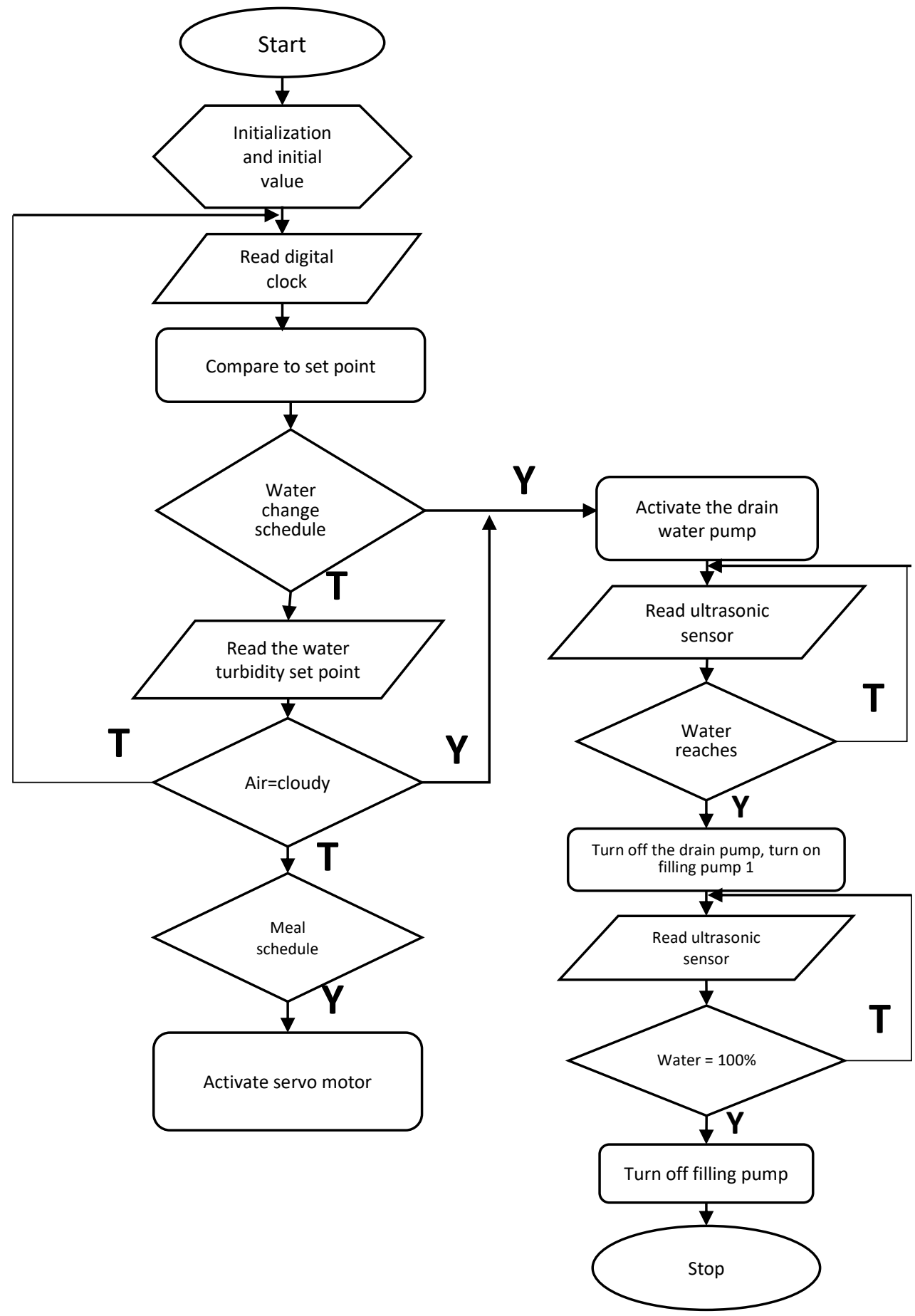

Figure 2. System flowchart

\section{Result and Discussion}

\subsection{M1632 LCD Display Testing}

LCD is one type of electronic display made with CMOS logic technology that works by not producing light but reflecting the light around it to the front-lit or transmitting light from the backlight. LCD functions as a data viewer in the form of characters, letters, numbers or graphics [14]. Microcontroller is used for orientation control, such as temperature control, LCD display appearance, digital signal processing and so on [15]. Here is a program made for LCD testing. 
Lcd_init(16);

lcd_gotoxy $(0,0)$;

lcd_putsf(“ALAT PEMBERSIH”);

lcd_gotoxy $(0,1)$;

lcd_putsf(“AKUARIUM AUTO”);

delay_ms(2000);

lcd_clear();

After running on the circuit, when activated the display will display a message "ALAT PEMBERSIH AKUARIUM AUTO"

\subsection{Turbidity Sensor Testing}

In principle, the turbidity sensor will read the intensity of the light scattered by the particles in the water. The more light that hits the LDR, the lower its resistance value. Conversely, if the light that hits the LDR is a little (dark), then the resistance value becomes even greater [16]. The electrode output signal which has an analog value will be processed by the microcontroller. Then the results obtained will be processed by the microcontroller so that a measurable value is obtained [17]. To test the sensor, it is enough to use a digital voltmeter. Here are the results of the tests carried out on the turbidity sensor.

Table 1. Turbidity Sensor Test Results

\begin{tabular}{cccc}
\hline Water Type & Sensor Voltage $(\mathrm{V})$ & Turbidity (NTU) & Water Condition \\
\hline Mineral water & 4.37 & 55 & Clear \\
Tea & 3.92 & 263 & Not clear \\
Strong tea & 3.36 & 317 & Concentrated \\
Milk & 1.15 & 1641 & Very thick \\
Soap water & 2.73 & 869 & Concentrated \\
Mud water & 1.21 & 1564 & Very thick \\
\hline
\end{tabular}

\subsection{Water Pump Test}

The water pump used is a plastic submersible water pump so that it is durable in water. In general, this pump is used in aquarium systems for the water filtration process. The performance of the pump is tested, namely the amount of water discharge that can be flowed per unit of time. For this test, a water container and a water measuring device are needed. In this experiment, a 5 liter gallon water container was used as a reservoir. The pump is immersed in water in the water supply container and then turned on to fill the gallon container to the brim. Take note of the time it takes for the charging process to take place. In order to make the results more accurate, 
several experiments were carried out and the average was taken. Here are the results of the tests carried out.

Table 2. Filling Pump Test Results

\begin{tabular}{ccc}
\hline Volume $(\mathrm{L})$ & Time $(\mathrm{s})$ & Debit $(\mathrm{L} / \mathrm{s})$ \\
\hline 1 & 5 & 0.20 \\
2 & 10 & 0.20 \\
3 & 16 & 0.18 \\
4 & 21 & 0.19 \\
5 & 25 & 0.20 \\
6 & 31 & 0.19 \\
7 & 36 & 0.19 \\
8 & 41 & 0.19 \\
9 & 47 & 0.19 \\
10 & 52 & 0.20 \\
\hline
\end{tabular}

The average water discharge from the above measurements is $0.19 \mathrm{~L} / \mathrm{s}$. From the test results above, the average discharge that can be flowed by the filling pump is $0.19 \mathrm{~L} / \mathrm{second}$.

Table 3. Drain Pump Test Results

\begin{tabular}{ccc}
\hline Volume $(\mathrm{L})$ & Time $(\mathrm{s})$ & Debit $(\mathrm{L} / \mathrm{s})$ \\
\hline 1 & 5 & 0.20 \\
2 & 11 & 0.18 \\
3 & 16 & 0.18 \\
4 & 22 & 0.18 \\
5 & 26 & 0.19 \\
6 & 32 & 0.18 \\
7 & 37 & 0.18 \\
8 & 42 & 0.19 \\
9 & 48 & 0.18 \\
10 & 54 & 0.18 \\
\hline
\end{tabular}

The average water discharge from the above measurements is $0.18 \mathrm{~L} / \mathrm{s}$. From the test results above, the average discharge that can be flowed by the drain pump is $0.18 \mathrm{~L} /$ second.

\subsection{Testing the RTC Timer}

RTC is an electronic clock in the form of a chip that can calculate time (from seconds to years) accurately and maintain / store the time data in real time [13]. In this automatic water change and feeding device, the IC DS1307 functions as an indicator of automatic feeding time for fish. The pins used are SDA and SCL which are connected to the microcontroller. The following are the results of the RTC testing carried out: 
Table 4. RTC Timer Test Results

\begin{tabular}{cccc}
\hline Day & $\begin{array}{c}\text { Replacement Time } \\
\text { Water }\end{array}$ & $\begin{array}{c}\text { Giving Time } \\
\text { Morning Feed }\end{array}$ & $\begin{array}{c}\text { Giving Time } \\
\text { Afternoon Feed }\end{array}$ \\
\hline 1 & $8: 00: 04$ & $8: 10: 02$ & $8: 15: 06$ \\
2 & $8: 00: 03$ & $8: 10: 01$ & $8: 15: 03$ \\
3 & $8: 00: 05$ & $8: 10: 08$ & $8: 15: 09$ \\
4 & $8: 00: 02$ & $8: 10: 09$ & $8: 15: 05$ \\
5 & $8: 00: 07$ & $8: 10: 08$ & $8: 15: 09$ \\
6 & $8: 00: 05$ & $8: 10: 07$ & $8: 15: 11$ \\
7 & $8: 00: 02$ & $8: 10: 12$ & $8: 15: 01$ \\
8 & $8: 00: 04$ & $8: 10: 11$ & $8: 15: 03$ \\
9 & $8: 00: 03$ & $8: 10: 06$ & $8: 15: 08$ \\
10 & $8: 00: 04$ & $8: 10: 09$ & $8: 15: 02$ \\
\hline
\end{tabular}

From the table above, it can be seen that the water replacement time is regulated through the program at 8 am, every 10 minutes after the water change, fish feed will be given. Feeding fish is an action that gives the right to live in the form of food for fish, so that they get energy and nutrients to carry out their lives [18]. Feeding can be done 2 times a day. Feeding goldfish is carried out 3 times a day, namely in the morning, afternoon and evening, as much as $3-4 \%$ of the total weight of the fish kept per day [19]-[20]. It can be concluded that the RTC timekeeping is quite accurate, the accuracy reaches $100 \%$ for hours and minutes. The time difference is only a matter of seconds.

\subsection{Testing the Water Level Sensor (Ultrasonic)}

Table 5. Atmega 8535 Microcontroller Test Results

\begin{tabular}{ccc}
\hline LCD Display $(\mathrm{mm})$ & Manual Measure $(\mathrm{mm})$ & \%Error \\
\hline 0 & 0 & $0 \%$ \\
11 & 10 & $10.0 \%$ \\
22 & 21 & $4.7 \%$ \\
31 & 30 & $3.3 \%$ \\
45 & 44 & $2.3 \%$ \\
58 & 61 & $4.9 \%$ \\
65 & 66 & $1.5 \%$ \\
77 & 79 & $2.5 \%$ \\
89 & 90 & $1.1 \%$ \\
97 & 98 & $1.0 \%$ \\
103 & 102 & $1.0 \%$ \\
111 & 112 & $0.9 \%$ \\
122 & 122 & $0 \%$ \\
131 & 130 & $0.8 \%$ \\
144 & 145 & $0.7 \%$ \\
152 & 150 & $1.3 \%$ \\
161 & 163 & $1.2 \%$ \\
173 & 177 & $2.3 \%$ \\
185 & 182 & $1.7 \%$ \\
194 & 191 & $1.6 \%$ \\
202 & 199 & $1.5 \%$ \\
\hline
\end{tabular}


The ultrasonic sensor emits ultrasonic waves to measure the distance of an object from the sensor. Ultrasonic waves are waves of mechanical energy and momentum propagation so that they propagate through the three elements as interactions with molecules and the energetic nature of the medium through which they pass [12]. The sensor is tested by comparing the sensor measurement results on the display with manual measurements. The results of the tests carried out on the ultrasonic sensor shown by Table 5 .

From the Table 5, it can be seen that there are differences in the results of manual measurements and the results of measuring tools, this is because at the time of measurement the water pump runs continuously so that ripples or water waves arise, thus sensor measurements have a larger error. However, the difference is only on the order of millimeters so it is not very meaningful for applications as water level monitoring in aquariums.

\section{Conclusion}

This automatic aquarium cleaner and fish feeder works great. The tool succeeded in changing the aquarium water when the water was cloudy or when the time was according to the specified schedule and the tool was also successful in feeding the fish according to the specified schedule accurately. The time difference between feeding fish and the schedule is only a matter of seconds.

\section{REFERENCES}

[1] Sirajudheen T. K., S. S. Salim, Bijukumar A. and B. Antony, "Problems and Prospects of Marine Ornamental Fish Trade in Kerala, India," Journal of Fisheries Economics and Development, vol. XV, no. 1, pp. 14-30, 2014.

[2] A. Karimah, I. Gumilar and Z. Hasan, "Analisis Prospektif Usaha Budidaya Ikan Hias Air Tawar di Taman Akuarium Air Tawar (TAAT) dan Taman Mini Indonesia Indah (TMII) Jakarta," Jurnal Perikanan dan Kelautan, vol. 3, no. 3, pp.145-156, 2012.

[3] R. K. Krissanggeni, Akuarium Laut di Yogyakarta, Skripsi, Yogyakarta: FT. Arsitektur Universitas Atma Jaya Yogyakarta, 2010.

[4] D. Satyani and B. Priono, "Penggunaan Berbagai Wadah untukPembudidayaan Ikan Hias Air Tawar," Jurnal Media Akuakultur, vol. 7, no. 1, pp. 14-19, 2012.

[5] E. Ihsanto and S. Hidayat, "Rancang Bangun Sistem Pengukuran $\mathrm{pH}$ Meter dengan Menggunakan Mikrokontroler Arduino Uno," Jurnal Teknologi Elektro, Universitas Mercu Buana, vol. 5 no. 3, pp. 130-137, 2014.

[6] M. Syahwil, Panduan Mudah Simulasi \& Praktek Mikrokontroler Arduino, Yogyakarta: Andi, 2013.

[7] B. Santoso and A. D. Arfianto, "Sistem Penggantian Air Berdasarkan Kekeruhan dan Pemberian Pakan Ikan Pada Akuarium Air Tawar Secara Otomatis Berbasis Mikrokontroler ATmega 16," Jurnal Ilmiah Teknologi dan Informasi ASIA, vol. 8, no. 2, pp. 33-48, 2014.

[8] A. A. Choir, Rancangan dan Uji Coba Otomatisasi Irigasi Kendi, Skripsi, Bogor: Depaertemen Teknik Sipil dan Lingkungan, Institut Pertanian Bogor, 2012.

[9] D. S. Lesmana, Ensiklopedia Ikan Hias Air Tawar, Jakarta: Penebar Swadaya, 2015.

[10] L. E. Manik, M. E. I. Najoan, A. M. Rumagit and B. A. Sugiarso, "Rancang Bangun 
Aplikasi Sistem Pendeteksi Kekeruhan Air Menggunakan Mikrokontroler AVR Atmega8535," Journal Teknik Elektro dan Komputer, vol. 2, no. 5, pp. 1-6, 2013.

[11] D. K. Rowe, A. M. Suren, M. Martin, J. P. Smith, B. Smith and E. Williams, Lethal Turbidity Levels for Common Freshwater Fish and Invertebrates in Auckland Streams, New Zealand: Auckland Regional Council Technical Publication, 2002.

[12] S. Hanan, Sunarno and I. Yuliarti, "Rancang Bangun Sistem Kendali Level Permukaan Air Menggunakan Mikrokontoler Arduino Uno untuk Pembudidayaan Hidroponik Metode Floating System," Unnes Physics Journal, vol. 5, no. 1, pp. 18-22. 2016.

[13] A. S. Ramadona, E. V. Haryanto and M. R. Tanjung, "Perancangan Alat Pengganti Air Aquarium Otomatis Berbasis Mikrokontroler ATMega 8," CSRID Journal, vol. 6, no. 1, pp. 1-10, 2014.

[14] A. Kadir, Panduan Praktis Mempelajari Aplikasi Mikrokontroler dan Pemrogramannya menggunakan Arduino, Yogyakarta: Andi, 2013.

[15] W. Budiharto, Aneka proyek Mikrokontroler: Panduan Utama untuk Riset/Tugas Akhir, Yogyakarta: Graha Ilmu, 2011.

[16] A. F. Maemunnur, Rancang Bangun Sistem Alat Ukur Turbidity Untuk Analisis Kualitas Air Berbasis Arduino Uno, Skripsi, Bandung: Departemen Pendidikan Fisika, FMIPA, Universitas Pendidikan Indonesia, 2015.

[17] Saidul and R. Pramana, "Pengontrolan pH Air secara Otomatis padaKolam Pembenihan Ikan Kerapu Macan Berbasis Arduino," Jurnal Teknik Elektro, Universitas Maritim Raja Ali Haji, 2016.

[18] S-Y. Sim, M. Rimmer, K. Williams, J. D. Toledo, K. Sugama, I. Rumengan and M. J. Phillips, Pedoman Praktis Pemberian dan Pengelolaan Pakan untuk Ikan Kerapu yang Dibudidaya. Thailand: Network of Aquaculture Centres in Asia-Pasific, 2005.

[19] H. R. Rukmana and H. H. Yudirachman, Sukses Budi Daya Ikan Mas Secara Intensif, Yogyakarta: Andi, 2016.

[20] J. Kohbara and I. Hidaka. "Demand-feeding pattern of yellowtail Seriola quinqueradiata in net-pens." Fisheries science vol. 68, pp. 930-933, 2002. 